\title{
The assessment of beauty salon client awareness of risk factors relating to skin and nail fungal infections of the feet*
}

\author{
Aleksandra TumalaA, Mariola Marchlewicz ${ }^{\mathrm{B}}$ \\ Pomeranian Medical University in Szczecin, Department of Aesthetic Dermatology, Powstańców Wlkp. 72, 70-111 Szczecin, Poland \\ A ORCID: 0000-0001-5572-4565; $\quad{ }^{\mathrm{B}}$ ORCID: 0000-0003-4915-9875 \\ $\triangle$ mariola.marchlewicz@pum.edu.pl
}

\begin{abstract}
Introduction: Fungal infections of the skin and nails are one of the most common skin diseases in the world. The ever-growing number of fungal infections is caused by genetic factors, lack of prevention and insufficient knowledge about risk factors relating to fungal infections.

The aim of the project was to assess the awareness of beauty salon clients to fungal infections of the skin and nails of the feet, with a particular emphasis on the factors contributing to infection.

Materials and methods: The study was conducted among 125 clients of beauty salons.

The data was collected via an anonymous questionnaire comprising 30 questions.

Results: The majority of respondents ( $84 \%$ of women and $70 \%$ of men) considered the swimming pool as the main risk
\end{abstract}

\section{INTRODUCTION}

Fungal infection of the skin and nails of the feet is an extremely common disease in Poland, with $42 \%$ of the adult population afflicted $[1,2,3]$.

Mycoses are caused by direct contact with an infected person and/or with infected objects. Most attention should be paid to floors in public places on which a foot without shoes is in contact, i.e. the bathing floor, in locker rooms, in the shower or in the sauna. Shoes, socks, towels, sponges and carpets can also be infected, as fungal spores can last up to several months in a favorable environment $[4,5,6]$.

The most important factors predisposing the development of tinea pedis are: excessive perspiration, intense sports, older age, circulatory disorders of the lower limbs, diabetes, overweight, drop in immunity and flatfoot $[4,5]$. Among the important acquired factors are: long-term use of immunosuppressive drugs during cancer treatment or after organ transplants, HIV infection, pregnancy and taking antibiotics and corticosteroids [2, 7].

Fungal infection of the nail in developed countries occurs in about $2-8 \%$ of the population, however, onychomycosis of factor for fungal infection of the feet. The respondents listed specialists to whom they would turn after noticing suspicious skin changes on their feet. These were dermatologists $(18 \%$ of responding women and $38 \%$ of responding men) as well as podologist $35 \%$ of responding women and $23 \%$ of responding men). However, the majority of respondents ( $45 \%$ of responding men and $33 \%$ of responding women) would use an over-thecounter antifungal medicine, easily obtained in a pharmacy, in case of suspected fungal nail infection (onychomycosis), without consulting a physician.

Conclusions: Most respondents know the risk factors contributing to fungal infections. However, a high percentage of them have low awareness of the actions to be taken when onychomycosis is suspected.

Keywords: fungal infections; onychomycosis; podiatry.

the feet is about 4-7 times more frequent than onychomycosis of the hand $[8,9,10]$.

Research shows that fungal nail infections are more common in people over 70. In this age group, the frequency of this dermatosis increases to $50 \%$. In adults, onychomycosis is even recorded 30 times more often than in children [8].

Older people often have problems with peripheral circulation, which may result in abnormal nail plate structure, which may be hyperkeratotic or brittle and fragile, facilitating the penetration of pathogens. In addition, mechanical disturbances may contribute to disorders of the nail plate structure. Moreover, the nail growth is slowed down, which also promotes the development of fungi [11].

People with a fungal infection tend to be unaware of this condition and do not undergo treatment. According to some authors this is due to low consciousness related to the problems of skin and nail mycosis [4].

The aim of the project was to assess the level of knowledge of beauty salon clients about mycosis of the skin and nails of the feet. 


\section{MATERIALS AND METHODS}

The research tool at work was the author's questionnaire, containing 30 questions about the knowledge of skin mycosis and toenails.

The research was carried out from October to December 2016 in the city of Szczecin in a selected beauty salon.

The study included 125 randomly selected respondents using the cosmetic services, comprising 85 women (68\%) and 40 men (32\%). Surveys were conducted among customers aged 20-60, where the average age was 34 years. The respondents are people with different education and different types of profession.

Statistical analysis of the results obtained was carried out using Microsoft Excel 2016.

\section{RESULTS}

The research carried out indicates that the term mycology was an unknown concept for $71 \%$ of respondents. The highest percentage of these had a secondary education (16\%). Of all subjects, $24 \%$ of people described mycology as a field for fungi. Such answers were given by people with at least secondary education, however, the largest group was composed of respondents with a master's degree (9\%) - Figure 1.

The results of the research presented in Figure 2 show that the largest group of men (38\%) noticing foot skin problems would go to a dermatologist. Podologist was mentioned by $23 \%$ of men surveyed. The next specialist, according to the men surveyed, is a general practitioner (10\%), while a further $3 \%$ were indicated by a dermatologist and podologist at the same time. The remaining $26 \%$ of men made mixed answers, including a podologist, dermatologist, cosmetologist, beautician, general practitioner, surgeon, orthopedist and pharmacist. Women, however, most often mentioned a podologist (35\%), as a specialist who should be visited by people concerned about skin lesions on their feet. Of all women, $18 \%$ thought that this specialist should be a dermatologist. Equally often, the podologist and dermatologist were mentioned at the same time. The general practitioner as a first-time contact for skin problems was indicated by $4 \%$ of the surveyed women. Mixed responses accounted for $25 \%$.

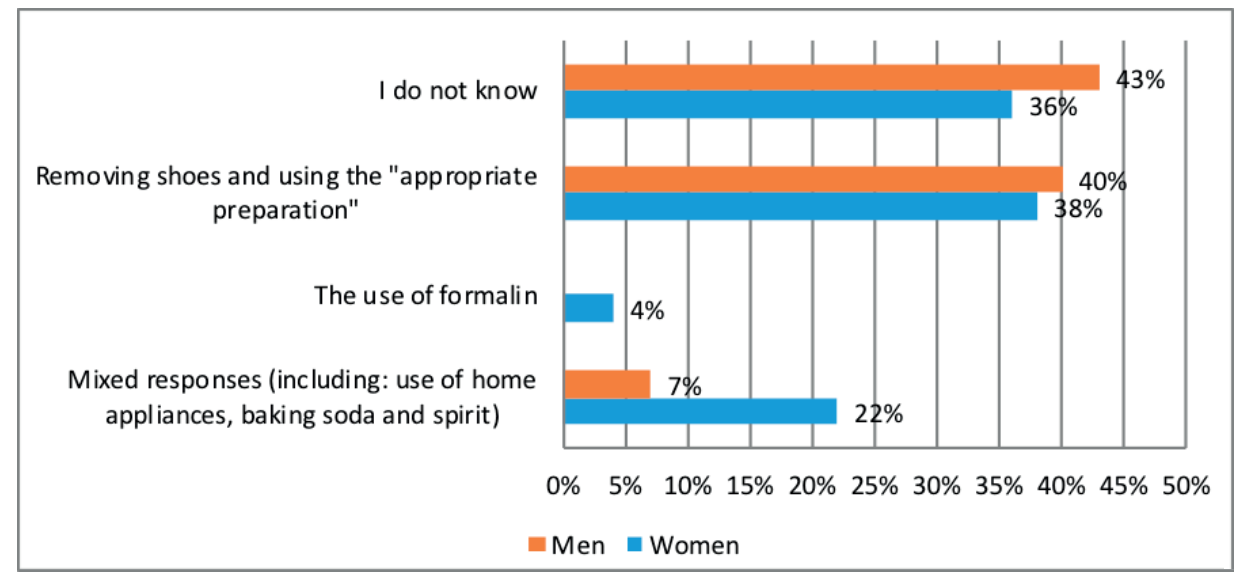

FIGURE 1. Knowledge of respondents about the science of "mycology" by level of education

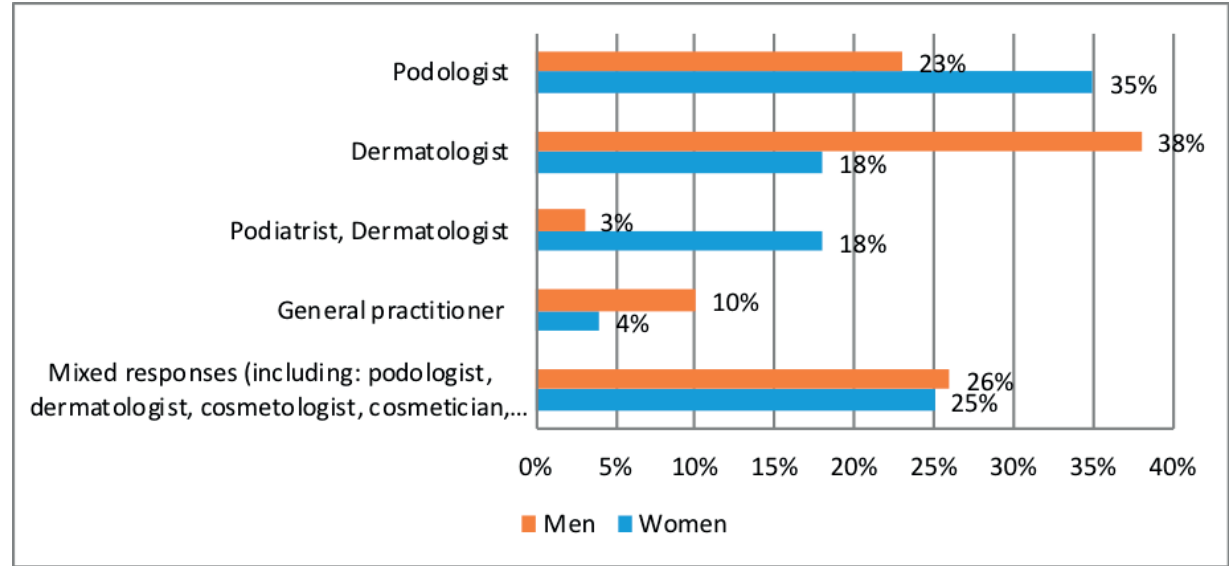

FIGURE 2. Specialists, to whom, according to the surveyed, one should go with skin changes on the feet 
Forty-five percent of men and 33\% of women would use an antifungal preparation available at a pharmacy without a prescription if someone suspected onychomycosis. A dermatological consultation is necessary according to $25 \%$ of men and $31 \%$ of women. Twenty-eight percent of men and $25 \%$ of women recognized a visit to the podologist for priority action. After observing disturbing symptoms on the nail plate, a mycological examination would be performed by only $2 \%$ of men and $11 \%$ of women (Fig. 3).
Table 1 shows the responses regarding the situations that promote fungal infection of the feet. Eighty-four percent of women and $70 \%$ of men described attending a swimming pool. According to both women (35\%) and men (28\%), direct contact of the foot without shoes with a potentially infected ground in the sauna, solarium, gym, or in other public places, is an significant factor favoring the development of foot fungal disease. Among the surveyed men, the reason often mentioned was the lack of hygiene (30\%). The same factor was indicated

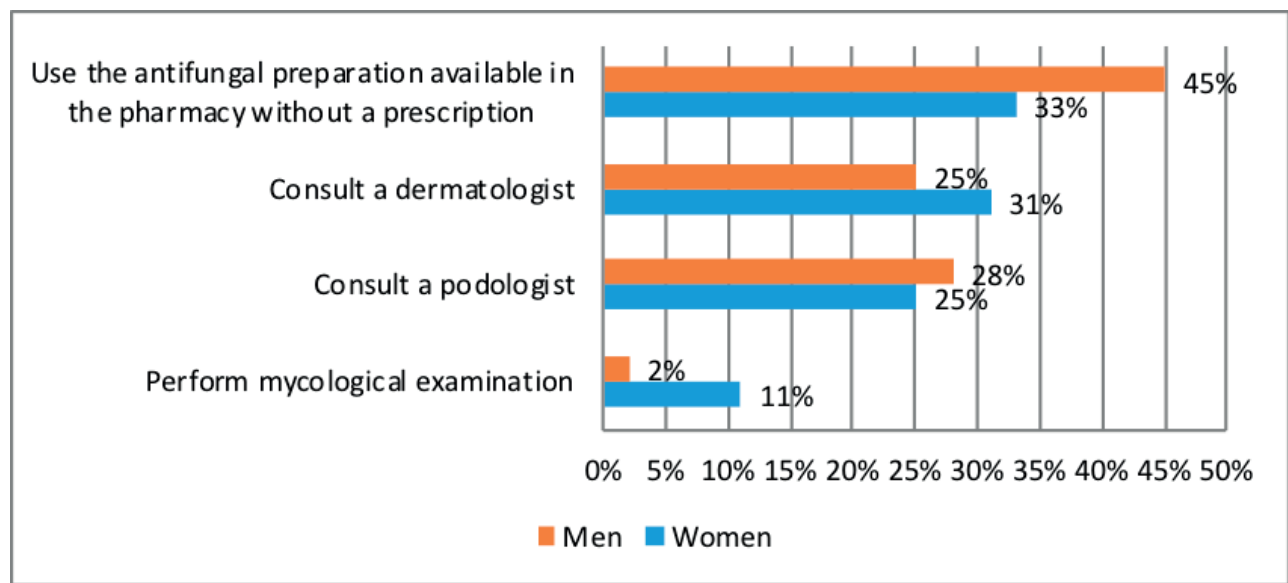

FIGURE 3. Respondents' reactions when suspicion of onychomycosis

by $11 \%$ of women surveyed. For foot care treatments in beauty salons, $18 \%$ of women classified this as a risk factor, no man considered it risky.

The research shows that shoes made of artificial materials were most often indicated by respondents as a predisposing

TABLE 1. List of situations conducive to fungal infection of the feet according to respondents

\begin{tabular}{lcc}
$\begin{array}{l}\text { Situations favoring fungal infection } \\
\text { of the feet }\end{array}$ & Women & Men \\
\hline $\begin{array}{l}\text { Attending the pool } \\
\text { Contact bare feet with potentially } \\
\text { infected substrate (sauna, solarium, } \\
\text { gym) }\end{array}$ & $34 \%$ & $70 \%$ \\
\hline $\begin{array}{l}\text { Use of public showers } \\
\text { No hygiene }\end{array}$ & $34 \%$ & $28 \%$ \\
\hline $\begin{array}{l}\text { Wearing used footwear } \\
\text { Wearing shoes made of artificial } \\
\text { materials }\end{array}$ & $11 \%$ & $23 \%$ \\
\hline $\begin{array}{l}\text { Trying shoes in the store } \\
\text { Excessive sweating }\end{array}$ & $15 \%$ & $15 \%$ \\
\hline $\begin{array}{l}\text { Inaccurate drying of feet after } \\
\text { bathing }\end{array}$ & $12 \%$ & $20 \%$ \\
\hline $\begin{array}{l}\text { Pedicure treatments } \\
\text { Lack of knowledge }\end{array}$ & $18 \%$ & $13 \%$ \\
\hline
\end{tabular}

factor for fungal nail infection. Over $70 \%$ of women and men gave such an answer. The second most often chosen factor was excessive sweating. Percentages differed depending on the sex, with the most frequently indicated factors, they are negligible. Larger discrepancies occur with a response that includes reduced immunity and circulatory disorders. The reduced immunity, for the condition that could promote a fungal nail infection, was recognized by $64 \%$ of women and $48 \%$ of men. Circulatory disorders indicated $14 \%$ more of the surveyed men compared to the surveyed women. All answers were marked by only $8 \%$ of respondents. They were people with a medical education (Fig. 4).

As it results from the conducted research, more than half of the respondents (60\%), knowledge about how to use antifungal prophylaxis, draws from the Internet. Of all the respondents, $25 \%$ of respondents knew these are obtained from a dermatologist, $21 \%$ from a podologist, and $13 \%$ from a general practitioner. The smallest percentage (6\%) are people using on-the-job training, or at university.

The vast majority of respondents (78\%) declared that they did not try on footwear in a shop without socks. The remaining $22 \%$ admitted that such situations happen. Among the respondents, $70 \%$ of people declared that they do not go to public places, such as a swimming pool, sauna, solarium or gym, without protective footwear. While, $30 \%$ of respondents gave an affirmative answer. Just over half of respondents (57\%) provided information that they did not shower in a hotel without safety footwear. The remaining $43 \%$ have direct contact with the ground in the shower, because they do not use sandals. 
Out of the surveyed people using items to rub the skin from the plantar surface of the feet, $78 \%$ admitted that they do not disinfect, $16 \%$ wash them under running water and soap, or pour boiling water, and only $6 \%$ use disinfectant. Among people using epidermal exfoliation products, the largest group (55\%) were respondents who exchanged these items once every 6 months. Once a month, $17 \%$ of respondents do it, $10 \%$ once a year, and less than once a year, $13 \%$ (Fig. 5).

The data presented in Figure 6 relate to the disinfection of shoes by respondents. Of all them, $43 \%$ of men and $36 \%$ of women do not know what to do to disinfect footwear. The most common response of women (38\%) was the washing of shoes and the use of a „suitable preparation”. This answer was also given by $40 \%$ of men. However, no one from this group of people has given a specific name for the antimicrobial agent in footwear. According to $4 \%$ of women, a formalin solution should be used to disinfect shoes. Among men, no such solution was recorded. In the answers of the remaining $22 \%$ of women and $7 \%$ of men there were suggestions for the use of baking soda and spirit and the placement of footwear in household appliances, such as: microwave oven, freezer, dishwasher.

\section{DISCUSSION}

Most respondents (71\%) did not know the term "mycology”. However, this does not necessarily mean low awareness, as it is a specialist term. Literature lacks research papers describing knowledge in this field, therefore it is not possible to compare this result with the analyzes of other authors. Assessing the respondents' state of knowledge regarding factors favoring fungal infections of the feet, the current study showed that the majority of respondents ( $84 \%$ women and $70 \%$ men) considered using the pool as the behavior most predisposed to fungal infection. Other factors most commonly described by the subjects include: contact of bare feet with potentially infected substrate (sauna, gym, solarium), use of public showers, lack of hygiene, wearing used and impermeable to air footwear. In the study of Penear-Zadarko et al., which included 1013 patients residing in various healthcare settings ( $64 \%$ of women and $36 \%$ of men), the most frequently indicated source of potential infection of foot mycosis was, similarly to the present study, being at the pool [12]. The percentage of people who gave such an answer is, however, lower, accounting for $23.8 \%$.

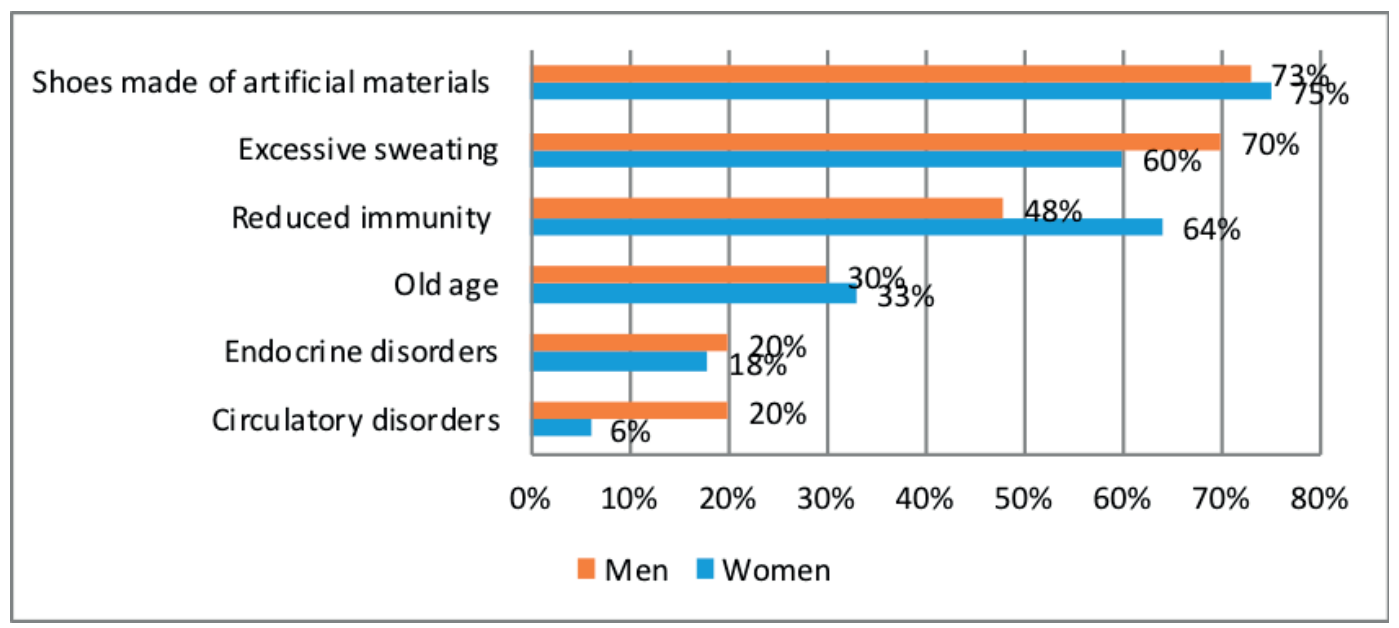

FIGURE 4. Factors predisposing to fungal nail infection according to respondents

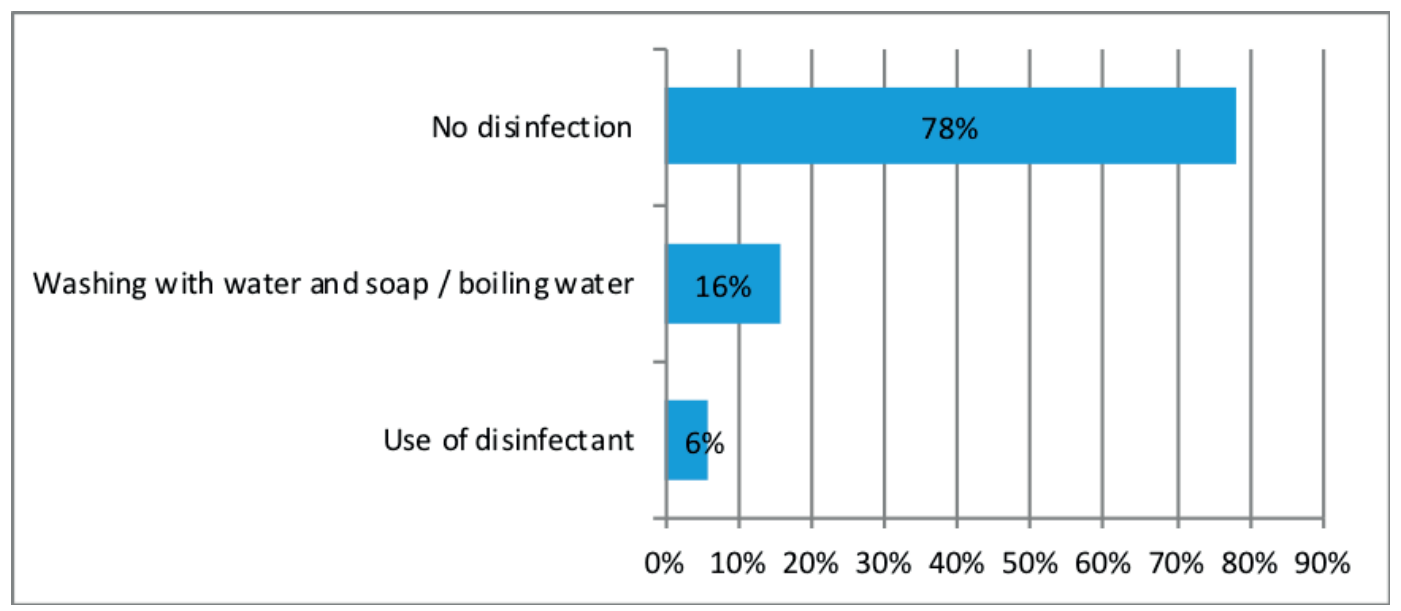

FIGURE 5. Methods of disinfecting objects used for exfoliation of the epidermis 


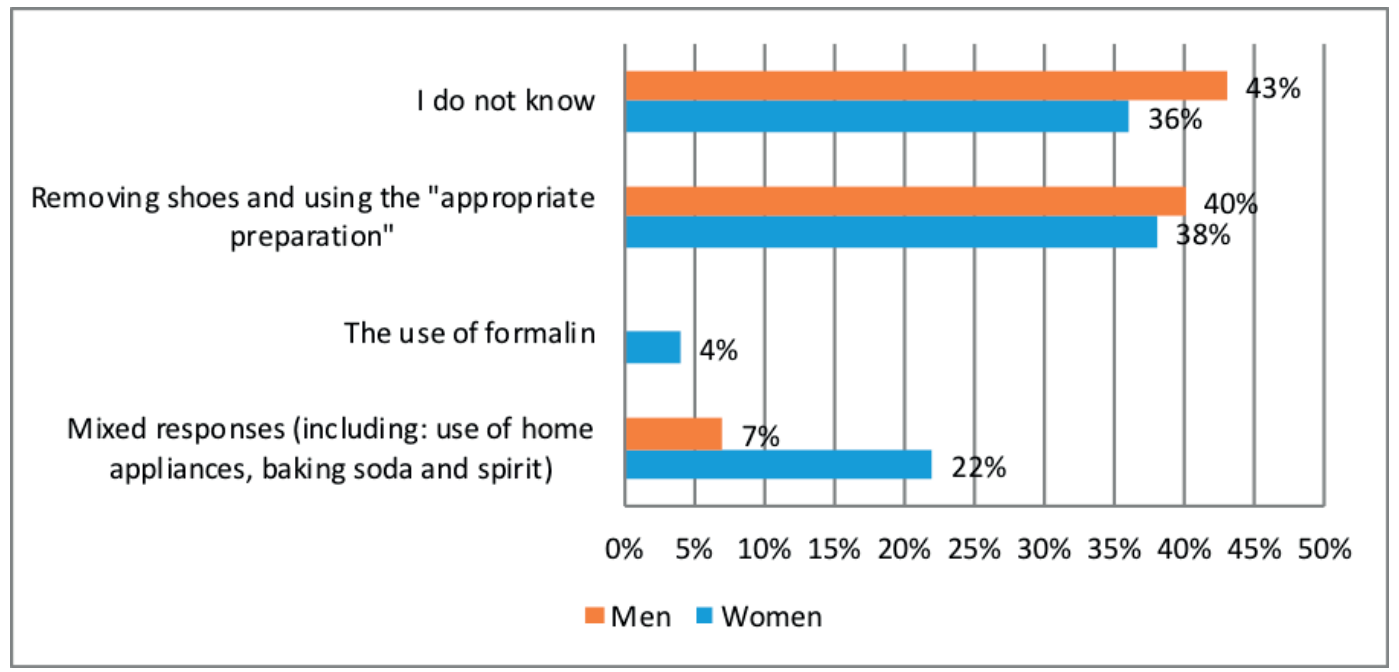

FIGURE 6. Knowledge of respondents regarding methods of disinfecting footwear

Frequently indicated behaviors, in the cited study, were also: using other people's personal belongings (23.7\%), contact with the sick (21.7\%) and lack of hygiene (20.7\%) [12]. Answers taking into account inappropriate footwear account for $6.1 \%$, however, the authors did not specify what kind of footwear to wear. Another article, which attempts to analyze knowledge about skin tinea, is based on a study by Szepietowski et al., in which 1865 people infected with skin and/or nail mycosis underwent dermatological treatment, including $53 \%$ of women and $47 \%$ of men. Most of the respondents (69\%) indicated all the correct answers regarding the pathways of fungal infection. People who chose only 1 factor, most often indicated wearing common footwear, using the pool or direct contact with an infected person [13].

Considering the results obtained in this study, it can be stated that for the largest group of respondents (60\%), the primary source of knowledge about antifungal prophylaxis was the Internet. People diagnosed by a dermatologist accounted for $25 \%$, by a podologist $21 \%$, and by a general practitioner only $13 \%$ of the respondents. Patients examined by Szepietowski et al. obtained information on fungal infections mainly in the family environment (35\%) [13]. In the study by Penar-Zadarko et al. the most frequent response was media (26\%). Only $19 \%$ of respondents in their study admit that they got any news about mycoses during visits to the clinic or hospital. According to the authors of this research, medical personnel do not provide information about the fungal infections caused by patients for various reasons. People working in health care institutions may have insufficient knowledge about mycoses, too little time to educate patients or lack proper educational materials [12].

The results of the current study indicate that after observing the potential symptoms of toenail fungus, the largest group of women (33\%) and men (45\%) would use an antifungal product bought in a pharmacy without a prescription. Twenty-nine percent of the respondents would seek a dermatologist's help, and almost the same (26\%) of all respondents would have a podologic consultation. Mycological examination would be performed by $2 \%$ of men and $11 \%$ women. A similar survey, assessing the behavior of patients after observing worrying changes suggesting the occurrence of ringworm, was carried out by Szepietowski et al. [13]. People who took part in the study, who would take the advice of a dermatologist, accounted for $80 \%$. However, the results of the research work include only the help of doctors and the opinion of family, making it difficult to compare the obtained data.

Analyzing our own research, it can be concluded that 78\% of respondents do not use disinfection of tools used for nail development after each use. It was also shown that a larger percentage of men (43\%), as compared to women (36\%), do not know what to do to disinfect footwear. Difficulties with comparison of results regarding disinfection by respondents result from the lack of publications on this subject.

In summary, because skin and nail mycosis in the foot can affect the quality of life of patients greatly, can cause pain, chronic discomfort during physical activity and while performing daily activities, it is important to properly care for the feet and maintain antifungal prophylaxis. The role of podologists and cosmetologists should be to make customers aware of beauty parlors with factors that favor fungal infections and methods of appropriate prophylaxis.

In the present study it was shown that there is a need to raise public awareness of antifungal prophylaxis and in the area of undertaken activities, when a fungal infection of the skin of the feet and nails is suspected.

\section{CONCLUSIONS}

1. The vast majority of clients of beauty salons know the factors that favor fungal infections and avoid risky behaviors.

2. A significant percentage of respondents, however, have low awareness of actions, what to do if you suspect a fungal infection.

3. The examined persons do not know the rules of proper foot care. 


\section{REFERENCES}

1. Sadowska-Przytocka A. Grzybice skóry i paznokci - algorytm postępowania. Prakt Lek 2015;120(7):20-1.

2. Galęba A, Gałązka M. Najczęstsze zakażenia grzybicze skóry i jej przydatków w praktyce lekarskiej - etiologia, profilaktyka i leczenie. Zakażenia 2014;14(3):20-6.

3. Hasse-Cieślińska M. Leczenie miejscowe dermatomikoz. Zakażenia 2012;12(1):78-83.

4. Krajewska-Kułak E, editor. Zarys mikologii dla pielęgniarek. Lublin: Wyd. Czelej; 2005

5. Szterling-Jaworowska M, Flisiak I, Chodyniecka B. Grzybica stóp. Zakażenia 2011;11(1):59-64.

6. Galęba A, Bajurna B, Marcinkowski JT, Głowacka MD. Most common diseases and ailments of feet - prevention and treatment. Part II. Hygeia Public Health 2014;49(1):62-8.
7. Barchnicka A. Nieleczona grzybica stóp a grzybica paznokci. Świat Med Farm 2011;119(3):50-5.

8. Romaszkiewicz A, Nowicki R. Grzybice paznokci. Zakażenia 2015;15(1):47-50.

9. Batycka-Baran A, Kozioł M, Baran W, Baran E. Nowe preparaty i metody stosowane w leczeniu grzybicy pazokci. Mikol Lek 2012;19(4):154-8.

10. Szczepietowski J, Reich A, Garłowska E, Kulig M, Baran E. Czynniki predysponujące do rozwoju grzybicy paznokci stóp w populacji polskiej. Mikol Lek 2005;12(4):231-4.

11. Olejniczak M, Seneczko F, Kozłowska M, Jarosiński D. Zakażenia grzybicze paznokci - czynniki usposabiające, profilaktyka. Dermatol Prakt 2013;5(2):32-8.

12. Penar-Zadarko B, Krajewska-Kułak E, Łukaszuk C. Ocena poziomu wiedzy pacjentów na temat grzybicy. Mikol Lek 2003;10(1): 31-7.

13. Szepietowski J, Baran W, Baran E, Melon M, Guryn M. Ocena wiedzy o grzybicy skóry wśród pacjentów na nią chorujących. Mikol Lek 2004;11(1):49-53. 